\title{
Ticari Bankalarm Etkinliklerinin VZA ve Malmquist TFV Endeksi ile İncelenmesi ${ }^{1}$
}

\section{Faruk SAHIN ${ }^{2}$ \\ Dilek ÖZDEMIR ${ }^{3}$}

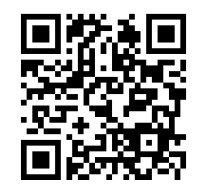

\begin{tabular}{ccc}
\hline $\begin{array}{c}\text { Geliş Tarihi/ Received } \\
\text { 29/07/2020 }\end{array}$ & Kabul Tarihi/ Accepted & Yayın Tarihi/ Published \\
$19 / 10 / 2020$ & $23 / 10 / 2020$ \\
\hline Citation/Atıf: Şahin, F. ve Özdemir, D., (2020), Ticari Bankaların Etkinliklerinin VZA ve \\
Malmquist TFV Endeksi ile Incelenmesi, Atatürk Üniversitesi İktisadi ve İdari Bilimler Dergisi, \\
34(4): Sayfa: $1559-1580$, DOI: https://doi.org/10.16951/atauniiibd.775609 \\
\hline
\end{tabular}

Öz: Bu çalışmanın amacı, Türkiye'de faaliyette bulunan ticari bankaların etkinlik ve verimliliklerini analiz etmektir. Bu amaç doğrultusunda Türkiye'de faaliyette bulunan 2005-2019 yıllarına ait kesintisiz verilerine ulaşılan 23 ticari bankanın etkinlik ve verimlilikleri Veri Zarflama ve Malmquist Toplam Faktör Verimliliği Analizi ile incelenmektedir. Analizde şube sayısı, personel sayısı, faiz dışı ve faiz giderleri girdi olarak kullanılırken faiz dışı ve faiz gelirleri çıktı olarak kullanılmıştır.

Etkinlik sonuçlarına genel olarak bakıldığında yabancı sermayeli bankalar diğer banka gruplarına göre daha etkin durumdadır. Yabancı sermayeli bankalardan etkinlikleri en yüksek düzeyde olan bankalar genellikle aktif büyüklüğü düşük bankalar olmakla birlikte belirlenen girdileri daha etkin kullanıp diğer bankalara kıyasla daha verimli çıktılar elde eden bankalardır. 2008 krizinin etkisiyle sektör olarak etkinlik oranlarında düşüş meydana gelmiştir. 2018 y1lına göre 2019 yılı sonuçlarına bakıldığında ise analize dahil edilen bankaların yaklaşık \%61'inin (23 bankadan 14'ü) etkinliklerinde artış meydana gelmiştir.

Ayrıca teknolojik etkinlikte hiçbir banka grubunda gerileme görülmemiştir. Teknolojik etkinlikte kamu sermayeli bankalar yabancı sermayeli ve özel sermayeli bankalara göre geri planda kalmaktadır. Toplam Faktör Verimliliğindeki Değişime göre analizde incelenen bankalardan gerileme gözlemlenmemektedir. Banka grubu bazında en yüksek ilerleme Yabancı Sermayeli Mevduat Bankalarına aittir.

Anahtar Kelimeler: Ticari Bankacılık, Bankalarda Etkinlik, Verimlilik, Veri Zarflama Analizi, Malmquist TFV Endeksi

Investigation of the Activities of Commercial Banks with DEA and Malmquist TFV Index

Abstract: The aim of this study is to analyze the efficiency and productivity of commercial banks operating in Turkey. For this purpose, the efficiency and productivity of 23 commercial banks operating in Turkey, whose continuous data of the years 2005-2018 were reached, have been analyzed through DEA and Malmquist Total Factor Productivity Analysis. In the analysis, the

${ }^{l}$ Not: Bu çalışma Dilek ÖZDEMIR danışmanlığında Atatürk Üniversitesi Sosyal Bilimler Enstitüsünde yürütülen Faruk ŞAHINN'in "Ticari Bankaların Etkinliklerinin VZA ve Malmquist Toplam Faktör Verimliliği Endeksi İle İncelenmesi" başlıkl yüksek lisans tezinden türetilmiştir.

${ }^{2}$ Arş̧ Gör. Atatürk Üniversitesi, İktisadi ve İdari Bilimler Fakültesi, İktisat Bölümü, Iktisat Politikası, https://orcid.org/0000-0002-9708-9085

${ }^{3}$ Doç. Dr. Atatürk Üniversitesi, İktisadi ve İdari Bilimler Fakültesi, İktisat Bölümü, İktisat Politikasl, https://orcid.org/0000-0002-8048-7730 
number of branches, number of personnel, non-interest and interest expenses were used as input, while non-interest and interest income were used as output.

Looking at the efficiency results in general, banks with foreign capital are more effective than other bank groups. The banks with the highest level of efficiency from foreign banks are banks with low asset size, but they are the ones that use the specified inputs more efficiently and obtain more efficient output compared to other banks. As a result of the 2008 crisis, there has been a decrease in efficiency rates as a sector. Considering the results of 2019 compared to 2018 , approximately $61 \%$ of the banks included in the analysis (14 out of 23 banks) increased their activities.

Moreover, there was no decline in technological efficiency in any bank group. In technological efficiency, public capital banks are in the background compared to foreign capital and private capital banks. According to the Change in Total Factor productivity, no decline is observed from the banks analyzed in the analysis. The highest progress per bank group belongs to Foreign Capital Deposit Banks.

Keywords: Commercial Banking, Efficiency in Banks, Productivity, Data Envelopment Analysis, Malmquist TFP Index

\section{Background}

\section{EXTENDED SUMMARY}

Effective operation of banks, which have a large place in the financial system, is very important for the regular functioning of the markets. Measuring whether the banks in the Turkish banking sector, which have been growing and developing at a high rate each year, are operating effectively is important both for the development of financial markets and for all decision-making units in the economy such as investors, firms, creditors and the government.

\section{Purpose}

The aim of this study was to examine the efficiency and productivity of commercial banks operating in Turkey through econometric analysis.

\section{Literature Review}

In Turkey and in the world, there are numerous academic studies on the efficiency and productivity of banking. While the number of personnel, number of branches, total deposits, total capital, interest expenses and non-interest expenses were selected as inputs, total deposits, total loan amount and net profit were used as output.

Method

In order to reveal the general course of the Turkish Banking sector, the change in the efficiency and productivity levels of the sector was analyzed by Data Envelopment Analysis and Malmquist Total Factor Productivity method based on the 2005-2019 data period of 23 commercial banks operating in the sector. Then, the efficiency ranking of the banks was determined with Super Efficiency Analysis. In the analysis, the number of branches, number of personnel, non-interest and interest expenses were used as input, while noninterest and interest income were used as output. The study is carried out on 23 banks in total, 3 with public capital, 7 with domestic private capital and 13 with foreign capital. The reason for the selection of the banks included in the analysis is that they operate uninterruptedly in the period of 2005-2019 and their data are 
accessed completely. Banks operating during these periods but whose data were not fully available were excluded from the analysis.

\section{Conclusions}

Effective work of banks is crucial for the development and growth of banks and the industry. The banking system, the basic building block of the financial system, needs to be solid, strong and stable.

As a result of the 2008 crisis, there has been a decrease in efficiency rates as a sector. Considering the results of 2018 compared to 2017, approximately $74 \%$ of the banks included in the analysis decreased in their activities. When the efficiency results are analyzed in general, banks with foreign capital are more effective than other bank groups. Banks with the highest level of effectiveness from banks with foreign capital are banks with low asset size, but they are the ones that use the specified inputs more efficiently and obtain more efficient output compared to other banks. In addition, there was no decline in technological efficiency in any bank group. In technological efficiency, public capital banks are in the background compared to foreign capital and private capital banks. According to Total Factor Productivity Change TFPC, no decline is observed from the banks included in the analysis. The highest progress per bank group belongs to Foreign Capital Deposit Banks. The change in TFPC is mostly affected by technological change.

\section{Giriş}

Finansal sistem, bir ekonomide fon fazlası olanların fona ihtiyacı olanlarla buluşturulmasını ve tasarrufların yatırıma dönüştürülmesini sağlayan bütüncül bir yapıdır. Finansal piyasalardaki fon transferleri, piyasaların sağlık $l_{1}$ işleyebilmesi için oldukça büyük bir öneme sahiptir. Finansal sistemin içinde bulunan fon kaynakları, yurtiçinde bulunan tasarruflar ile birlikte ülke içine dış ülkelerden aktarılan yurtdışı tasarruflar toplamıdır (Çolak ve Öçal, 1999: 19).

Dünyanın çoğu yerinde fon transferinin gerçekleştirilmesi için farklı işlevlerde finansal kurumlar vardır. Bankalarda bu finansal kurumlar içindeki en büyük paya sahip kurumlardır. Türkiye'de finansal sistemin aktif büyüklük olarak \%87,2'sini oluşturan bankalar (BDDK, 2018) ülke ekonomisinde de söz sahibidirler. Piyasayı sürekli finanse eden bu kurumlar, verdikleri kredilerle gerek yatırımcıları gerekse de tüketicileri destekleyerek yatırımların ve harcamaların canlı tutulmasını sağlamaktadırlar. Verdiği krediler ve yatırımlara destekleri sonucunda belli bir faiz geliri veya kar pay1 elde etmektedirler. Bankaların temel amacı diğer işletmelerde olduğu gibi karlarını maksimize etmektir.

Ülke ekonomisi içinde büyük bir yere sahip olan bankaların etkin çalışması piyasaların düzenli işleyişi açısından oldukça önemlidir. Bankaların performans analizi yatırımcılar, alacaklılar ve hükümetler tarafından sürekli takip edilmektedir. Piyasada faaliyet gösteren bankaların etkin çalışıp çalışmadıklarını ölçmek için birçok yöntem bulunmaktadır. Etkinlik ölçme yöntemleri oran analizi 
ve sınır etkinliği olarak iki başlıkta incelenmektedir. Oran analizinde daha çok bankaların yayınladığı raporlardan elde edilen değerlerin oranlanmasıyla bulunan rasyoların yorumlanması yapılmaktadır. Sınır etkinliği metodunda ise oranlar değil de verilerin gerçek değerleri yazılmaktadır. Bu analiz yöntemi sade bankacılık sistemi değil sağlık, askeriye ve eğitim gibi birçok alanda kullanılabilmektedir. Sinır yöntemleri de parametrik ve parametrik olmayan yöntemler olarak alt başlıklara ayrılmaktadır. Çalışmada etkinlik ölçümünde parametrik olmayan sınır testlerinden veri zarflama modeli kullanılmışır. Faaliyette bulunan bankaların verimlilik düzeylerini ölçmek için ise verimlilik analizinde en çok başvurulan yöntem olan Malmquist Toplam Faktör Verimliliği Endeksi (MTFV) kullanılmıştır.

Veri zarflama yönteminde karar verme birimlerini oluştururken aynı sektörde faaliyet gösteren ve benzer girdiler kullanılıp benzer çıktılar ortaya çıaran birimlerin seçilmesi gerekmektedir (Buğan, 2015: 40). Çalışmada karar birimleri bankalardır. Dolayısıyla 2005 yılından 2019 yılına kadar faaliyette olan ve verilerine kesintisiz bir şekilde ulaşılan ticari bankalar üzerinde analiz gerçekleştirilmiştir.

Toplam 53 bankanın bulunduğu bankacılık sektöründe 34 mevduat, 13 kalkınma ve yatırım ve 6 da katılım bankası faaliyet göstermektedir. Analize kalkınma ve yatırım bankaları ile katılım bankaları dahil edilmemiştir. Kalkınma ve yatırım bankalarının dahil edilmeme sebebi işleyiş ve yapısının diğer banka türlerinden tamamen farklı olmasıdır. Katılım bankalarının dahil edilmemesinin sebebi ise kullanılan girdi ve çıktıların (faiz ve faiz dış1 gelir-gider) katılım bankaları açısından bir karşıı̆ı̆ının olmamasıdır. 34 mevduat bankasının toplam aktif büyüklügü yüzde 87 iken toplam 20 olan kalkınma ve yatırım bankası ile katılım bankalarının sektördeki toplam payı yüzde 13 civarındadır. 34 tane mevduat bankasından kesintisiz verilerine ulaşılan 23 tane banka analize dahil edilmiştir. Analize dahil edilen 23 bankanın aktif büyüklük toplamı ise bankacılık sektörünün yaklaşık olarak \%86'sını oluşturmaktadır. Girdi olarak şube sayısı, personel sayısı, faiz giderleri, faiz dışı giderler ve çıtı olarak faiz gelirleri ile faiz dışı gelirler kullanılmıştır.

Çalışma 3 kamusal sermayeli, 7 yerli özel sermayeli ve 13 yabancı sermayeli olmak üzere toplam 23 banka üzerinden yapılmaktadır. Analize dahil edilen bankaların seçilme nedeni 2005-2019 döneminde kesintisiz faaliyette bulunması ve verilerine eksiksiz şekilde ulaşılmasıdır. Bu dönem içinde faaliyette bulunan ancak verilerinin tamamına ulaşılamayan bankalar analiz dışında tutulmuştur.

\section{Literatür}

Bankacılık etkinliği ve verimliliği üzerine Türkiye'de birçok çalışma yapılmıştır. Bankacılık etkinliği hesaplanırken genel olarak Veri Zarflama Analizi kullanılırken verimlilik incelemelerinde ise Malmquist TFV Endeksi metodu kullanılmıştır. Bunlardan bazıları özet şekilde incelenmiştir. 
Behdioğlu ve Özcan, 2009 yılında yapmış oldukları çalışmada 1999-2005 yılları arasında Türkiye'de faaliyet gösteren 29 ticari bankanın etkinliklerini veri zarflama metodu ile incelemişlerdir. Girdi olarak personel sayısı, faiz dışı giderler, şube sayısı ve faiz giderleri seçilirken çıktı olarak ise toplam mevduat, toplam kredi miktarı ve net kar kullanılmıştır. Ortalama etkinlik yüzdeleri yüzde 43,3 olarak bulunmuştur. Yabancı sermayeli bankaların etkinlik yüzdeleri diğer banka gruplarının etkinlik yüzdelerine göre daha yüksek düzeyde bulunmuştur.

Sufian ve Noor 2009 yılında yapmış oldukları çalışmada 2001-2006 yılları arasında 16 MENA ülkesinde bulunan bankaları kapsayan etkinlik analizi yapmışlardır. Girdi olarak toplam mevduatlar ve toplam sermaye kullanılırken çıktı olarak toplam krediler, faaliyet dışı gelirler ve toplam yatırımlar kullanılmıştır. Bankaların etkinliği ile banka büyüklükleri, bankaların kullandırdıkları krediler, sermaye ve karlılığın pozitif yönlü bir ilişkide olduğu, takipteki krediler ile de negatif ilişkili olduğu tespit edilmiştir.

Budak 2011 yılında yaptığ çalışmada Türkiye'de faaliyette bulunan 22 ticari bankanın 2008-2010 y1lları arasındaki etkinliklerini veri zarflama analizi ile incelemiştir. Girdi olarak şube sayısı, personel sayısı ile faiz ve faiz dışı giderler toplamı kullanılırken çıktı olarak toplam mevduat, toplam krediler ile faiz ve faiz dışı gelirler toplamı kullanılmıştır. Yapılan çalışma sonucunda kamu sermayeli bankaların özel ve yabancı sermayeli bankalara göre daha etkin olduğu sonucuna varılmıştır. 2008-2010 yılları arasında bankaların etkinliklerinde şube ve personel sayısı olan girdilerdeki artışlara rağmen çıktılarda artışların düşük olmasindan dolayı azalmalar meydana gelmektedir.

Jreisat ve Paul 2011 yılında yapmış oldukları çalışmada Ürdün bankacılık sektöründe faaliyette bulunan 13'ü yerli 3'ü de yabancı sermayeli toplam 16 bankanın 1996-2007 yılları arasındaki verimlilik düzeylerini Veri Zarflama Analizi metodunu kullanarak inlemişlerdir. Analizde girdi olarak işgücü ve toplam mevduatı kullanılırken çıktı olarak toplam borçlar ve diğer yatırımlar kullanılmıştır. Analiz sonucunda büyük olan bankaların küçük olanlara göre daha etkin olduğu ve yerli bankaların da yabancılardan daha etkin olduğu tespit edilmiştir.

Akyüz, Yıldız ve Kaya 2013 yılında yaptıkları çalışmada BİST'te işlem gören 11 mevduat bankasının 2007-2011 yılları arasındaki verimliliklerini ölçmüşlerdir. Girdi olarak özsermaye, mevduat, faiz giderleri kullanılırken, çıktı olarak faiz gelirleri ve net kar kullanılmıştır. Dönem bazında değerlendirildiğinde 2008-2009 döneminde MTFV değişiminde artış meydana gelirken diğer dönemlerde azalış meydana gelmiştir.

Bektaş 2013 yılında yapmış olduğu çalışmada 2007-2011 yılları arasında 11 özel sermayeli ve 11 yabancı sermayeli bankanın Veri Zarflama Analizi metodu kullanarak etkinliklerini ölçmüşlerdir. Analizde girdi olarak toplam mevduat, faiz giderleri ve faiz dış1 giderler kullanılırken çıktı olarak ise toplam krediler ve alacaklar, faiz gelirleri ve faiz dışı gelirler kullanılmıştır. Etkin oldukları tahmin edilen yabancı ve özel bankaların, Mann-Whitney U testi 
sonuçlarına göre uyumlu olduğu ve bankalar arasında istatistiksel olarak fark olmadığ ortaya koyulmuştur.

Ada ve Dalkılıç 2014 yıllarında yapmış oldukları çalışmada 2009-2011 yılları arası Türkiye ve Malezya da faaliyette bulunan İslami Bankaların verimliliklerini karşılaştırmalı olarak analiz etmişlerdir. Girdi olarak toplam varlıklar ve özkaynaklar kullanılırken çıktı olarak toplam mevduat ile net kar/ zarar kullanılmıştır. 2009 yılı haricinde Malezya bankalarının Türkiye'de faaliyet gösteren bankalara göre ölçek etkinliği olarak ortalamaları daha yüksek çıkmıştır.

Büyükakın ve Kapkara 2016 yılında yapmış oldukları çalışmada Türkiye'de faaliyet gösteren 3 katılım bankasının 2010-2015 yılları arasındaki etkinlik ve verimliliklerini veri zarflama analizi aracılığıyla incelemişlerdir. Girdi olarak toplam fonlar çıktı olarak ise kullandırılan fonlar seçilmiştir. Analiz sonucunda Türkiye Finans Katılım Bankası diğer bankalara göre daha etkin çıkmıştır.

Bolaman Avcı ve Öztaş 2016 yılına yapmış oldukları çalışmada 1998-2014 yılları arasında Türkiye'de faaliyette bulunan ticari bankaların etkinliklerini analiz etmişlerdir. Girdi olarak toplam mevduat personel sayısı ve şube sayısı kullanılırken çıktı olarak toplam krediler kullanılmıştır. CCR modeline göre 1998 yılında bir banka etkin olurken 2014 yılında beş banka etkin konumda bulunmaktadir.

Khan, Samsudin ve Islam 2017 yılında yapmış oldukları çalışmada Endonezya, Malezya, Tayland ve Filipinlerde faaliyette bulunan 72 bankanın 1998-2012 yılları arasındaki etkinliklerini VZA yöntemi ile ölçmüşlerdir. Analizde girdi olarak sabit varlıklar, toplam mevduatlar ve personel giderleri kullanılırken çıktı olarak ise net borçlar ve diğer getirili varlıklar kullanılmıştır. Analiz sonucunda Malezya ve Tayland'in Endonezya ve Filipinler'e göre daha etkin olduğu ve 2003 yılından sonra tüm bankaların etkinlerinin düzenli olarak arttı̆̆ gözlemlenmiştir.

Çelik, Öncü ve Yenice 2018 yılında yaptıkları çalışmada, Türkiye'de faaliyet gösteren ticari bankaların 2008-2016 yılları arasında etkinlikleri veri zarflama metodu ile ölçülmüştür. Girdi olarak toplam mevduat, personel sayısı ve faiz giderleri kullanılırken çıktı olarak faiz gelirleri ve krediler kullanılmıştır. CCR varsayımı sonucuna göre Deutsche Bank ve Arap Türk Bankası diğer bankalara göre daha etkin çıkmıştır.

Öner ve Demirel Arıcı 2018 yılında yapmış oldukları çalışmada Türkiye bankacılık sektöründe faaliyette bulunan 27 bankanın 2012-2017 arasındaki etkinlik ve verimliliklerini incelemişlerdir. Etkinlik analizinde VZA, verimlilik analizinde de MTFV endeksi yöntemi kullanılmıştır. Analizde girdi olarak şube sayısı, faiz giderleri ve faiz dışı giderler kullanılırken çıktı olarak ise faiz gelirleri ve faiz dışı gelirler kullanılmıştır. Çalışma dönemi içinde etkin banka sayısında azalış olduğu gözlemlenmiştir. Etkinlikte esas belirleyici olan faktörün bankaların mülkiyet yapısı olduğu, bankaların aktif büyüklükleri bakımından büyük, orta ve küçük ölçekli olmaları veya BIST'te işlem görüp görmemelerinin 
etkinlik belirleyicilerinden olmadığı gözlemlenmiştir. Ayrıca Malmquist TFV analizinde ise yıl bazında tüm banka gruplarında düşüşler olduğu tespit edilmiştir.

\section{Veri ve Yöntem}

Bankacılık sektöründe girdi ve çıktı için seçilebilecek değişkenlerin oldukça fazla olması sebebiyle bu değişkenlerin belirlenmesi konusunda herhangi bir uzlaşma bulunmamaktadır. Bu anlaşmazlığın sebeplerinden biri çalışmanın amacıdır. Yani üretim etkinliği, piyasa etkinliği veya karlılık etkinliklerinden hangisi incelenecekse değişkenler ona göre belirlenmektedir. Anlaşmazlığın diğer bir sebebi ise örneklem büyüklüğü ve istatistiki sınırlamalardır (Hajıhassanıasl ve Nasiri, 2019: 79). Çalışmamızda üretim etkinliği yaklaşımına göre girdi ve çıktı değişkenleri belirlenmiştir. Çalışmada kullandığımız değişkenler Tablo 1'de verilmiştir.

Tablo: 1. Çalışmada Kullanılan Değişkenler

\begin{tabular}{c|c}
\hline Girdiler & Çıktılar \\
\hline Şube Sayısı & Faiz Gelirleri \\
Personel Sayısı & Faiz Dışı Gelirler \\
Faiz Giderleri & \\
Faiz Dı̧̧ Giderler & \\
\hline
\end{tabular}

Bir ticari bankada genel gelir ve gider kalemleri faiz giderleri, faiz dışı giderler, faiz gelirleri ve faiz dışı gelirler olarak sınıflandırılmaktadır. Faiz giderlerinin içindeki en büyük pay mevduat için ödenen faizdir. Bunun yanı sıra diğer bankalardan alınan krediler için ödenen faiz de önemli bir kalemdir.

Faiz dışı giderler, vergiler, personel giderleri, kira giderleri ve amortisman gideri gibi çoğunlukla sabit olan giderlerdir.

Faiz gelirlerinin büyük çoğunluğu bankaların kullandırdığı kredilerden elde ettiği faiz gelirleridir. Diğer bankalara kullandırılan fonlardan elde edilen faiz gelirleri de önemli bir yere sahiptir. Faiz dışı gelirler, sermaye piyasası işlem gelirleri, komisyon gelirleri (EFT, havale, kredi kartı, döviz işlemleri v.b. işlemler) ve kambiyo gelirleri gibi işlemlerden elde edilmektedir.

Analizde kullanılan bankaların girdi ve çıktı değişkenlerini oluşturan veri seti, 2005-2019 yılları arasında yayınlanmış olan BDDK, TBB resmi sitelerindeki veriler ile bankaların yıllık faaliyet raporlarındaki bilanço ve gelir tablolarından düzenlenmiştir.

Çalışmada bankaların etkinliğinin belirlenmesi amacıyla sınır etkinliğinin parametrik olmayan yöntemlerinden olan Veri Zarflama Analizi (VZA) kullanılmıştır. Süper etkinlik analizi ile de etkin bankaların etkinlik dereceleri belirlenmiştir. VZA'ya tamamlayıcı olarak verimlilik analizlerinde kullanılan Malmquist Toplam Verimlilik Endeksi yöntemi uygulanmıştır. 


\subsection{Veri Zarflama Analizi}

Veri Zarflama Analizi metodunun fikri ilk olarak Farrell (1957)'a dayandırılmaktadır (Eken ve Kale, 2011: 890). Bu metod 1978'de Charnes, Cooper ve Rhodes (CCR) tarafindan yapılan "Measuring the Efficiency of Decision Making Units" adlı çalışma ile ölçeğe göre sabit getiri modeli uygulanarak literatüre kazandırılmıştır. Bu çalışmada üretim sınırları ve teknik etkinlik tahmini eklenip Farrell'in teorisi genişletilip daha verimli bir yöntem haline getirilmiştir. Banker, Chanes ve Cooper (BCC) 1984 yılında yaptıkları çalışmada ölçeğe göre değişken getiri modelini geliştirmişlerdir. Önceleri kar amacı gütmeyen işletmelerde kullanılan bu yöntem daha sonraları karı amaç edinen işletmelerde de kullanılmaya başlanmıştır (Charles ve Kumar, 2012: 13 ve Ray, 2004: 2). VZA modelinin bankacilık sektöründe ilk uygulamas1 ise Sherman ve Gold (1985) tarafindan gerçekleştirilmiştir.

VZA, doğrusal programlama esasına dayalı olarak çalışan, birbirine benzer özelliklerde olan ekonomik karar verme birimlerinin üretmiş oldukları mal ve hizmetlerin etkinliklerinin ölçümü için ortaya çıkarılmış olan parametresiz bir etkinlik ölçüm modelidir.

Karar verme birimlerinin (KVB) etkinliğinin belirlenmesi için en uygun girdi ve çıktı değişkenlerinin belirlenmesi gerekmektedir. Seçilecek girdi çıktı değişkenlerinin tüm KVB'lerde ortak olarak kullanılıyor olması gerekmektedir. VZA modelinin etkin olabilmesi için girdi ve çıktı değişkenlerinin sayısının çok olması istenmektedir. Seçilen girdi sayısına " $m$ ", çıktı sayısına ise "s" denildiği zaman KVB sayısı araştırmanın güvenirliği açısından " $\mathrm{m}+\mathrm{s}+1$ " eşitinden küçük olmamalıdır (Boussofiane v.diğ, 1991: 3). Bu bağlamda çalışmada KVB olan banka sayısı (23) bu koşulu $(4+2+1=7)$ sağlamaktadır.

Veri zarflama analizi CCR ve BCC olarak iki model olarak hesaplanmaktadır. Bu modeller girdi ve çıktı odaklı olarak ayrılmaktadır. Yapmış olduğumuz veri zarflama analizinde girdi odaklı CCR modeli kullanılmıştır. CCR modeli Charnes, Cooper ve Rhodes' in 1978 yılında yaptığı çalışmada ölçeğe göre sabit getiri varsayımı altında oluşturdukları ilk veri zarflama modelidir (Charnes vd., 1978: 429-444). Girdiye yönelik CCR modelini matematiksel olarak aşağıdaki şekilde hesaplanmaktadır (Bakırcı, 2006:130); 


$$
\begin{aligned}
& E_{k}=\operatorname{Min} \alpha-\varepsilon\left(\sum_{i=1}^{m} S_{i}^{-}\right)-\varepsilon\left(\sum_{r=1}^{p} S_{r}^{+}\right) \\
& \left(\sum_{j=1}^{n} X_{i j} \lambda_{j}+S_{i}^{-}-\alpha X_{i k}\right)=0 \\
& \left(\sum_{j=1}^{n} Y_{r j} \lambda_{j}+S_{i}^{+}-Y_{r k}\right)=0 \\
& \lambda_{j} \geq 0 \\
& S_{i}^{+} \geq 0 \\
& j=1, \ldots, n \\
& r=1, \ldots ., p \\
& i=1, \ldots, m
\end{aligned}
$$

$\alpha$ : Göreli etkinliği ölçülen $\mathrm{k}$ karar biriminin girdilerin in ne kadar azaltılabileceğini belirleyen büzülme katsayis 1 ,

$\mathrm{Y}_{\mathrm{rk}}$ : k. karar birimi tarafindan üretilen r. çıkt1,

$\mathrm{X}_{\mathrm{ik}}: \mathrm{k}$. karar birimi tarafindan kullanlan i. girdi,

$Y_{r j}: j$. karar birimi tarafindan üretilen $r$. çıktı,

$X_{i j}$ : j. karar birimi tarafindan kullanlan i. girdi,

$\lambda_{\mathrm{j}}:$ j. karar biriminin aldığ 1 yoğunluk değeri,

$\mathrm{S}_{\mathrm{i}}^{-}: \mathrm{k}$. karar biriminin i. değerine ait atıl değer.

$\mathrm{S}_{\mathrm{i}}^{+}: \mathrm{k}$. karar biriminin $\mathrm{r}$. değerine ait atıl değer,

$\varepsilon$ : Yeterince küçük pozitif bir say1 (örneğin 0,00001) olarak tanmlanmaktadir.

Girdiye yönelik BCC modeli ise matematiksel olarak aşağıdaki biçimde hesaplanmaktadır. (Banker vd., 2004:346-347)

$$
\begin{aligned}
& \mathrm{E}_{\mathrm{k}}=\operatorname{Min} \alpha-\varepsilon\left(\sum_{\mathrm{i}=1}^{\mathrm{m}} \mathrm{S}_{\mathrm{i}}^{-}\right)-\varepsilon\left(\sum_{\mathrm{r}=1}^{\mathrm{p}} \mathrm{S}_{\mathrm{r}}^{+}\right) \\
& \left(\sum_{\mathrm{j}=1}^{\mathrm{n}} \mathrm{X}_{\mathrm{ij}} \lambda_{\mathrm{j}}+\mathrm{S}_{\mathrm{i}}^{-}-\alpha \mathrm{X}_{\mathrm{ik}}\right)=0 \\
& \left(\sum_{\mathrm{j}=1}^{\mathrm{n}} \mathrm{Y}_{\mathrm{rj}} \lambda_{\mathrm{j}}+\mathrm{S}_{\mathrm{i}}^{+}-\mathrm{Y}_{\mathrm{rk}}\right)=0 \\
& \sum_{\mathrm{j}=1}^{\mathrm{n}} \lambda_{\mathrm{j}}=1 \\
& \lambda_{\mathrm{j}} \geq 0 \\
& \mathrm{~S}_{\mathrm{i}}^{-} \geq 0 \\
& \mathrm{~S}_{\mathrm{i}}^{+} \geq 0 \\
& \mathrm{j}=1, \ldots, \mathrm{n} \\
& \mathrm{r}=1, \ldots, \mathrm{p} \\
& \mathrm{i}=1, \ldots, \mathrm{m}
\end{aligned}
$$

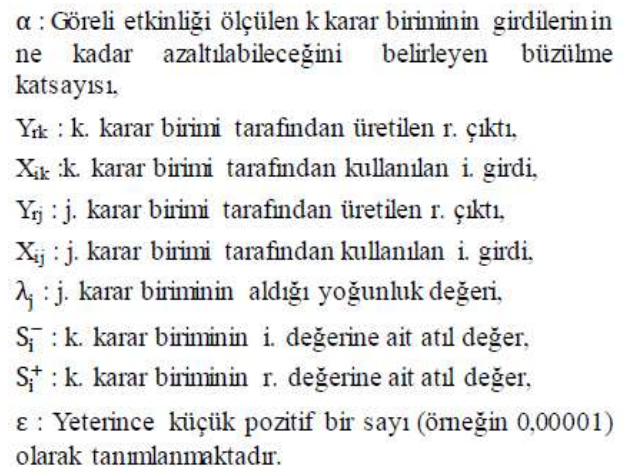

KVB'lerin etkinsizlikleri iki sebebe dayandığ 1 varsayılmaktadır. Birincisi KVB'lerin etkinsiz bir biçimde yönetilmesidir. İkinci sebep ise KVB'lerinin çalışma şartları içinde diğer KVB'lere kıyasla dezavantajlı konumda bulunmalarıdır. Etkinsizlik durumunu ölçmek için ölçek etkinliği hesaplanmaktadır. Teknik Etkinlik (TE) modeli olarak adlandırılan CCR modeli aracılığıyla bulunan etkinlik değeri ile Saf Etkinlik Değeri (STE) olarak adlandırılan BCC modeli aracılığıyla üretilmiş olan etkinlik değerlerinin 
oranlanması sonucu Ölçek Etkinliği bulunmaktadır. Bu iki etkinlik değeri arasındaki ilişki şu şekilde yazılabilir:

\section{ÖE $=\mathrm{CCR} / \mathrm{BCC}$}

CCR ve BCC değerlerinin oranlanması sonucunda bulunan ÖE değeri 1'e eşit olduğu durumlarda KVB'lerinin optimal ölçekte faaliyette bulunduğu söylenebilir. Eğer CCR/BCC oranı1'den küçükse ilgili KVB'nin optimal ölçekte olmadığı ve ölçeğini artırması gerektiği söylenebilmektedir. (Ulucan ve Karacabey, 2002: 106 ve Özer ve Topçuoğlu, 2017: 9).

\subsection{Malmquist Toplam Faktör Verimliliği}

Malmquist (1953) tarafından geliştirilen Malmquist Toplam Faktör Verimliliği (MTFV), Caves, Christensen ve Diewert'ın 1982 yılında yaptığı katkılarla endeks olarak literatüre girmiştir. Verimlilik analizlerindeki değişimi incelemek için en fazla başvurulan yöntem olan MTFV endeksinin amac1, üretkenliğin belirli zaman sınırı içinde ölçülmesi ve incelenmesidir (Keskin Benli, 2012: $371 \&$ Abbas vd. 2015). MTFV ortak teknolojiye sahip tüm veri noktalarının nispi uzaklık oranlarının hesaplanarak, iki veri noktası arasındaki toplam faktör verimliliğindeki değişimi ölçmeye yarayan bir veri zarflama yöntemidir (Deliktaş, 2002: 252). Birden fazla kullanılan girdi ve çıktının kullanıldığ bu endekste verimlilikteki ilerlemenin ve gerilemenin durumu ve zaman içerisindeki teknolojik değişimi açıklamaktadır (Tone, 2004: 203-227).

Fare ve arkadaşları 1994 yılında yapmış oldukları çalışmada esas alınmış olan $\mathrm{t}$ dönemi ve bunu izleyen $\mathrm{t}+1$ dönemi arasındaki çıktıya göre Malmquist TFV değişim endeksi aşağıdaki gibi hesaplanmaktadır (Akyüz vd.,2013: 11);

$$
M_{o}\left(x^{t}, y^{t}, x^{t+1}, y^{t+1}\right)=\sqrt{\left[\frac{D_{o}^{t}\left(x^{t+1}, y^{t+1}\right)}{D_{o}^{t}\left(x^{t}, y^{t}\right)} \times \frac{D_{o}^{t+1}\left(x^{t+1}, y^{t+1}\right)}{D_{o}^{t+1}\left(x^{t}, y^{t}\right)}\right]}
$$

Malmquist Endeksinin (ME) aldığı değerler aşağıdaki gibi yorumlanmaktadır (Ateş ve Esmer, 2013: 77 \& Büyükakın ve Kapkara, 2016: 11).

ME $<1$ ise; $t$ yllından $(t+1)$ yılına geçerken, performansta düşüş ve verimlilikte azalış meydana gelmiştir.

$\mathrm{ME}>1$ ise; $\mathrm{t}$ yllından $(\mathrm{t}+1)$ yllına geçerken, performansta yükselme ve verimlilikte artış meydana gelmiştir.

$\mathrm{ME}=1$ ise; $\mathrm{t}$ yılından $(\mathrm{t}+1)$ yılına geçerken, performansta değişim meydana gelmemiştir 


\section{Analiz Sonuçları}

Etkinlik ve verimlilik analizinin incelendiği çalışmada 3 kamusal sermayeli, 7 yerli özel sermayeli ve 13 yabancı sermayeli olmak üzere 23 bankanın 2005-2018 yıllarını kapsayan analizde şube sayısı, personel sayısı, faiz dışı ve faiz giderleri girdi olarak kullanılırken faiz dışı ve faiz gelirleri çıktı olarak kullanılmıştır. Çalışmada her banka VZA için KVB'yi ifade etmekte ve dolayısıyla her bir KVB'ler arasındaki kıyaslamalar bankalara göre etkinlik değerini ortaya koymaktadır.

Veri Zarflama Analizi ile bankaların etkinlik düzeylerinin bulunması ve etkinlik düzeylerinin sıralanmasına yardımcı olması için süper etkinlik analizi Excel tabanlı DEA-Frontier Programı aracılığıyla yapılmıştır. Malmquist Toplam Faktör Verimliliği Endeksinin bulunması için ise DEAP adlı uygulama kullanılmıştır.

\subsection{Veri Zarflama Analizi Sonuçları}

VZA hesaplamasında girdi odaklı model kullanılmıştır. Çünkü girdi miktarının azaltılıp çıktı miktarının sabit olması, genel olarak yöneticiler tarafindan istenen ve kontrolü daha kolay olan bir durumdur. Ayrıca, ölçeğe göre sabit getiri varsayımı altında elde edilen etkinlik değerleri (CCR) hesaplanmıştır. Bankalara göre girdi odaklı CCR modelleriyle hesaplanan etkinlik değerleri ve ölçeğe göre getiri sonuçları 2005-2019 yılları için Tablo 2'de gösterilmiştir.

Elde edilen CCR model sonuçlarına göre kamu sermayeli bankalar içerisinde Halk bankasının şube sayısı, personel sayısı, faiz ve faiz dışı giderlerin faiz ve faiz dışı gelirler açısından 2005-2019 yılları aralığında diğer kamu sermayeli bankalara kiyasla daha etkin olduğu görülmüştür. Kamu sermayeli bankaların tamamının 2019 yılındaki etkinlik düzeylerinde artış gözlemlenmiştir. 
Ticari Bankalartn Etkinliklerinin VZA ve Malmquist TFV Endeksi ile Incelenmesi

Tablo 2: CCR Etkinlik Analiz Sonucu (2005-2011)

\begin{tabular}{|c|c|c|c|c|c|c|c|c|c|c|c|c|c|c|}
\hline \multirow{3}{*}{ Yillar } & \multicolumn{14}{|c|}{ CCR Etkinlik Analizi } \\
\hline & \multicolumn{2}{|l|}{2005} & \multicolumn{2}{|l|}{2006} & \multicolumn{2}{|l|}{2007} & \multicolumn{2}{|c|}{2008} & \multicolumn{2}{|l|}{2009} & \multicolumn{2}{|l|}{2010} & \multicolumn{2}{|l|}{2011} \\
\hline & $\mathbf{C C R}$ & Ö.G. & CCR & Ö.G. & CCR & Ö.G & CCR & ÖG & CCR & ÖG & CCR & ÖG & CCR & Ö.G. \\
\hline \multicolumn{15}{|c|}{ Kamusal Sermayeli Mevduat Bankaları } \\
\hline T.C. Ziraat Bankası A.Ş. & 1,00 & Sabit & 0,98 & Azalan & 0,88 & Azalan & 0,83 & Azalan & 0,86 & Azalan & 1,00 & Sabit & 0,72 & Azalan \\
\hline Türkiye Halk Bankası A.Ş. & 0,88 & Azalan & 1,00 & Sabit & 1,00 & Sabit & 1,00 & Sabit & 1,00 & Sabit & 1,00 & Sabit & 1,00 & Sabit \\
\hline Türkiye Vakıflar Bankası A.Ş. & 1,00 & Sabit & 1,00 & Sabit & 1,00 & Sabit & 0,93 & Azalan & 0,90 & Azalan & 0,88 & Azalan & 1,00 & Sabit \\
\hline \multicolumn{15}{|c|}{ Özel Sermayeli Mevduat Bankaları } \\
\hline Akbank T.A.Ş. & 1,00 & Sabit & 1,00 & Sabit & 1,00 & Azalan & 0,99 & Azalan & 0,94 & Azalan & 0,92 & Azalan & 0,76 & Azalan \\
\hline Anadolubank A.Ş. & 0,76 & Artan & 0,84 & Azalan & 0,71 & Azalan & 0,64 & Azalan & 0,65 & Azalan & 0,67 & Azalan & 0,68 & Azalan \\
\hline Fibabanka A.Ș. & 0,58 & Azalan & 0,78 & Artan & 0,89 & Azalan & 0,68 & Azalan & 0,48 & Azalan & 0,51 & Azalan & 0,60 & Artan \\
\hline Şekerbank T. A.Ş. & 0,93 & Azalan & 0,91 & Artan & 0,89 & Azalan & 0,79 & Azalan & 0,85 & Azalan & 0,67 & Azalan & 0,70 & Artan \\
\hline Türk Ekonomi Bankası A.Ş. & 0,83 & Artan & 0,86 & Azalan & 0,64 & Azalan & 0,55 & Azalan & 0,50 & Azalan & 0,56 & Azalan & 0,59 & Azalan \\
\hline Türkiye İş Bankası A.Ş. & 0,99 & Azalan & 0,90 & Azalan & 0,85 & Azalan & 0,74 & Azalan & 0,96 & Azalan & 0,90 & Azalan & 0,89 & Azalan \\
\hline Yapı ve Kredi Bankası A.Ş. & 0,77 & Azalan & 0,90 & Azalan & 0,89 & Azalan & 0,70 & Azalan & 0,67 & Azalan & 0,91 & Azalan & 0,90 & Azalan \\
\hline \multicolumn{15}{|c|}{ Yabancı Sermayeli Bankalar A.Ș. } \\
\hline Alternatifbank A.Ș. & 1,00 & Sabit & 1,00 & Sabit & 0,89 & Azalan & 0,80 & Azalan & 1,00 & Sabit & 1,00 & Sabit & 0,68 & Artan \\
\hline Arap Türk Bankası A.Ş. & 1,00 & Sabit & 0,97 & Artan & 0,86 & Artan & 1,00 & Sabit & 1,00 & Sabit & 1,00 & Sabit & 1,00 & Sabit \\
\hline Bank Mellat & 0,87 & Artan & 0,92 & Artan & 0,91 & Artan & 0,75 & Azalan & 0,79 & Artan & 1,00 & Sabit & 1,00 & Sabit \\
\hline Burgan Bank A.Ş. & 0,66 & Artan & 0,77 & Artan & 0,79 & Artan & 0,92 & Artan & 0,70 & Artan & 0,60 & Azalan & 0,53 & Artan \\
\hline Citibank A.Ș. & 1,00 & Sabit & 1,00 & Sabit & 1,00 & Sabit & 0,78 & Azalan & 1,00 & Sabit & 1,00 & Sabit & 1,00 & Sabit \\
\hline Denizbank A.Ş. & 0,91 & Azalan & 0,95 & Azalan & 0,69 & Azalan & 0,68 & Azalan & 0,92 & Azalan & 0,88 & Azalan & 1,00 & Sabit \\
\hline Habib Bank Limited & 1,00 & Sabit & 0,97 & Artan & 1,00 & Sabit & 1,00 & Sabit & 1,00 & Sabit & 1,00 & Sabit & 1,00 & Sabit \\
\hline HSBC Bank A.S. & 0,95 & Azalan & 0,99 & Azalan & 0,77 & Azalan & 0,64 & Azalan & 0,62 & Azalan & 0,69 & Azalan & 0,82 & Azalan \\
\hline ICBC Turkey Bank A.Ș. & 0,77 & Artan & 0,86 & Azalan & 0,70 & Azalan & 0,61 & Azalan & 0,60 & Azalan & 0,58 & Azalan & 0,62 & Azalan \\
\hline ING Bank A.Ș. & 0,86 & Artan & 0,83 & Azalan & 0,65 & Azalan & 0,61 & Azalan & 0,67 & Azalan & 0,67 & Azalan & 0,71 & Azalan \\
\hline QNB Finansbank A.Ş. & 1,00 & Sabit & 1,00 & Sabit & 0,79 & Azalan & 0,68 & Azalan & 0,70 & Azalan & 0,72 & Azalan & 0,67 & Azalan \\
\hline Turkland Bank A.Ș. & 0,77 & Artan & 0,68 & Artan & 0,58 & Azalan & 0,51 & Azalan & 0,51 & Azalan & 0,71 & Azalan & 0,61 & Azalan \\
\hline Türkiye Garanti Bankası A.Ș. & 0,92 & Azalan & 0,96 & Azalan & 1,00 & Sabit & 0,84 & Azalan & 0,84 & Azalan & 0,84 & Azalan & 0,91 & Azalan \\
\hline
\end{tabular}


Tablo 2 Devamı: CCR Etkinlik Analiz Sonucu (2012-2019)

\begin{tabular}{|c|c|c|c|c|c|c|c|c|c|c|c|c|c|c|c|c|}
\hline \multirow{3}{*}{ Yillar } & \multicolumn{16}{|c|}{ CCR Etkinlik Analizi } \\
\hline & \multicolumn{2}{|c|}{2012} & \multicolumn{2}{|l|}{2013} & \multicolumn{2}{|l|}{2014} & \multicolumn{2}{|c|}{2015} & \multicolumn{2}{|c|}{2016} & \multicolumn{2}{|l|}{2017} & \multicolumn{2}{|l|}{2018} & \multicolumn{2}{|l|}{2019} \\
\hline & $\mathrm{CCR}$ & Ö.G. & CCR & Ö.G. & CCR & Ö.G. & CCR & Ö.G. & CCR & Ö.G. & CCR & Ö.G. & CCR & Ö.G. & CCR & Ö.G. \\
\hline \multicolumn{17}{|c|}{ Kamusal Sermayeli Mevduat Bankaları } \\
\hline T.C. Ziraat Bankası A.S.. & 0,87 & Azalan & 0,87 & Azalan & 0,94 & Azalan & 0,93 & Azalan & 1,00 & Sabit & 1,00 & Sabit & 0,80 & Azalan & 0,96 & Azalan \\
\hline Türkiye Halk Bankası A.Ș. & 1,00 & Sabit & 1,00 & Sabit & 1,00 & Sabit & 1,00 & Sabit & 1,00 & Sabit & 0,98 & Artan & 0,77 & Azalan & 1,00 & Sabit \\
\hline Türkiye Vakıflar Bankası A.Ş. & 0,92 & Azalan & 0,81 & Azalan & 1,00 & Sabit & 0,93 & Azalan & 0,93 & Azalan & 1,00 & Sabit & 0,76 & Azalan & 1,00 & Sabit \\
\hline \multicolumn{17}{|c|}{ Özel Sermayeli Mevduat Bankaları } \\
\hline Akbank T. A.Ş. & 0,77 & Azalan & 0,81 & Azalan & 0,89 & Azalan & 0,96 & Azalan & 1,00 & Sabit & 1,00 & Sabit & 0,95 & Azalan & 0,98 & Azalan \\
\hline Anadolubank A.Ş. & 0,71 & Azalan & 0,69 & Azalan & 0,69 & Azalan & 0,76 & Azalan & 0,76 & Azalan & 0,86 & Artan & 1,00 & Sabit & 1,00 & Sabit \\
\hline Fibabanka A.Ş. & 0,68 & Azalan & 0,63 & Artan & 0,73 & Azalan & 0,79 & Azalan & 0,87 & Artan & 0,98 & Artan & 0,80 & Azalan & 1,00 & Sabit \\
\hline Şekerbank T A.S... & 1,00 & Sabit & 0,71 & Azalan & 0,73 & Azalan & 0,85 & Azalan & 0,83 & Azalan & 0,83 & Azalan & 0,43 & Azalan & 0,64 & Artan \\
\hline Türk Ekonomi Bankası A.Ş. & 0,61 & Azalan & 0,62 & Azalan & 0,69 & Azalan & 0,76 & Azalan & 0,80 & Azalan & 0,76 & Azalan & 0,49 & Azalan & 0,67 & Azalan \\
\hline Türkiye İş Bankası A.Ş. & 0,87 & Azalan & 0,69 & Azalan & 0,70 & Azalan & 0,78 & Azalan & 0,83 & Azalan & 0,83 & Azalan & 1,00 & Sabit & 1,00 & Sabit \\
\hline Yapı ve Kredi Bankası A.Ş. & 0,74 & Azalan & 0,68 & Azalan & 0,72 & Azalan & 0,79 & Azalan & 0,81 & Azalan & 0,85 & Azalan & 0,74 & Azalan & 0,88 & Azalan \\
\hline \multicolumn{17}{|c|}{ Yabancı Sermayeli Bankalar } \\
\hline Alternatifbank A.Ș. & 1,00 & Sabit & 0,91 & Artan & 0,98 & Artan & 1,00 & Sabit & 1,00 & Sabit & 0,95 & Artan & 1,00 & Sabit & 1,00 & Sabit \\
\hline Arap Türk Bankası A.Ş. & 1,00 & Sabit & 0,99 & Azalan & 0,99 & Azalan & 1,00 & Sabit & 1,00 & Sabit & 1,00 & Sabit & 0,85 & Azalan & 0,90 & Artan \\
\hline Bank Mellat & 1,00 & Sabit & 1,00 & Sabit & 1,00 & Sabit & 1,00 & Sabit & 1,00 & Sabit & 1,00 & Sabit & 1,00 & Sabit & 1,00 & Sabit \\
\hline Burgan Bank A.Ş. & 0,58 & Artan & 0,55 & Azalan & 0,65 & Artan & 0,78 & Artan & 0,97 & Artan & 1,00 & Sabit & 1,00 & Sabit & 0,70 & Azalan \\
\hline Citibank A.Ş. & 1,00 & Sabit & 1,00 & Sabit & 1,00 & Sabit & 1,00 & Sabit & 1,00 & Sabit & 1,00 & Sabit & 1,00 & Sabit & 1,00 & Sabit \\
\hline Denizbank A.Ş. & 0,76 & Azalan & 0,77 & Azalan & 0,72 & Azalan & 0,78 & Azalan & 0,77 & Azalan & 0,79 & Azalan & 0,49 & Azalan & 0,75 & Azalan \\
\hline Habib Bank Limited & 1,00 & Sabit & 0,97 & Artan & 0,97 & Artan & 1,00 & Sabit & 0,94 & Artan & 0,82 & Artan & 0,62 & Artan & 0,76 & Artan \\
\hline HSBC Bank A.Ş. & 0,66 & Azalan & 0,64 & Azalan & 0,58 & Azalan & 0,62 & Azalan & 0,70 & Azalan & 0,99 & Azalan & 0,72 & Azalan & 0,65 & Azalan \\
\hline ICBC Turkey Bank A.Ş. & 0,73 & Artan & 1,00 & Sabit & 0,72 & Azalan & 0,79 & Azalan & 0,67 & Azalan & 0,78 & Azalan & 0,62 & Azalan & 0,69 & Artan \\
\hline ING Bank A.Ș. & 0,95 & Azalan & 0,70 & Azalan & 0,72 & Azalan & 0,83 & Azalan & 0,81 & Azalan & 0,82 & Azalan & 0,75 & Azalan & 0,73 & Azalan \\
\hline QNB Finansbank A.Ș. & 0,82 & Azalan & 0,69 & Azalan & 0,69 & Azalan & 0,77 & Azalan & 0,77 & Azalan & 0,73 & Artan & 0,60 & Azalan & 0,75 & Azalan \\
\hline Turkland Bank A.Ș. & 0,63 & Artan & 0,65 & Artan & 0,72 & Artan & 0,72 & Artan & 0,79 & Artan & 0,78 & Artan & 0,59 & Azalan & 0,43 & Artan \\
\hline Türkiye Garanti Bankası A.Ş. & 0,77 & Azalan & 0,79 & Azalan & 0,79 & Azalan & 0,86 & Azalan & 0,94 & Azalan & 0,95 & Azalan & 0,79 & Azalan & 0,90 & Azalan \\
\hline
\end{tabular}


Tablo 2 elde edilen sonuçlara göre 2005-2019 yılları arasında özel sermayeli bankalardan Akbank toplam etkin $(\mathrm{CCR}=1)$ olduğu yıl sayısı bazında diğer bankalara kıyasla daha etkin olduğu belirlenmiştir. Türkiye Ekonomi Bankası analizin yapıldığı yıllar aralığında diğer bankalara göre etkinlik olarak daha düşük düzeydedir. Özel sermayeli bankalara genel olarak bakılacak olursa Anadolubank ve Türkiye İş Bankası hariç diğer bankaların 2018 yılındaki etkinlik düzeylerinde düşüş meydana gelirken 2019 yılında ele alınan tüm bankaların etkinlik düzeylerinde artış yaşanmıştır.

Analiz sonucuna göre yabancı sermayeli bankalardan en etkin banka Citibank olurken bunu Bank Mellat, Arap Türk Bankası ve Alternatifbank olarak takip etmişlerdir. 2019 yılı analiz sonuçlarına bakıldığında ise Alternatifbank, Bank Mellat, ve Citibankın etkinliklerini korudukları görülmektedir.

Analiz sonuçlarına genel olarak bakıldığında 15 yılın 14'ünde etkin olan Citibank en etkin banka olurken bunu 15 yılın 12'sinde etkin olan Halk Bankası takip etmiş̧ir. Bankaların 2018 yılında etkinliklerinde önemli oranlarda düşüş meydana gelmiştir. 2018 yılına kıyasla 2019 yılında 14 bankanın etkinliğinde artış meydana gelirken 8 banka etkin olarak çalışmaya devam etmiştir. Geriye kalan 3 bankanın ise etkinliklerinde önemli ölçüde azalma meydana gelmiştir.

\subsection{Süper Etkinlik Analizi Sonuçları}

Veri zarflama analizi sonuçlarında çıkan değerler ya 1'e eşittir ya da 1'den daha düşüktür. Analiz sonucunda çıkan "1" değeri KVB'nin o dönemde etkin olduğunu göstermektedir. Ancak aynı dönem içinde birden çok etkin olan birim olduğu durumlarda hangisinin daha etkin olduğunu belirlemek için sıralama yapmak gerekmektedir. Bu sıralamanın yapılabilmesi için Andersen ve Petersen (1993)'ın geliştirdikleri süper etkinlik modeli kullanılmaktadır. Süper etkinlik analizi sonucunda da en yüksek değere sahip olan KVB en etkin olanı olarak belirlenmektedir. 
Tablo 3: 2005-2018 Yılları Arasına 23 Ticari Bankanın Süper Etkinlik Analizi Sonuçları

\begin{tabular}{|c|c|c|c|c|c|c|c|c|c|c|c|c|c|c|c|}
\hline & 2005 & 2006 & 2007 & 2008 & 2009 & 2010 & 2011 & 2012 & 2013 & 2014 & 2015 & 2016 & 2017 & 2018 & 2019 \\
\hline \multicolumn{16}{|c|}{ Bankalar } \\
\hline \multicolumn{16}{|c|}{ Kamusal Sermayeli Mevduat Bankaları } \\
\hline T.C. Ziraat Bankası A.S. & 1,257 & 0,983 & 0,877 & 0,834 & 0,857 & 1,006 & 0,717 & 0,871 & 0,865 & 0,939 & 0,928 & 1,132 & 1,095 & 0,796 & 0,959 \\
\hline Türkiye Halk Bankası A.Ş. & 0,879 & 1,340 & 1,517 & 1,387 & 1,474 & 1,452 & 1,430 & 1,372 & 1,372 & 1,256 & 1,285 & 1,177 & 0,983 & 0,772 & 1,188 \\
\hline Türkiye Vakıflar Bankası A.Ş. & 1,402 & $\underline{1,383}$ & 1,199 & 0,930 & 0,897 & 0,878 & 1,352 & 0,923 & 0,805 & 1,287 & 0,930 & 0,926 & 1,024 & 0,765 & 1,423 \\
\hline \multicolumn{16}{|c|}{ Özel Sermayeli Mevduat Bankaları } \\
\hline Akbank T.A.S. & 1,147 & 1,020 & 0,999 & 0,993 & 0,937 & 0,924 & 0,762 & 0,767 & 0,809 & 0,892 & 0,958 & 1,032 & 1,067 & 0,947 & 0,975 \\
\hline Anadolubank A.S. & 0,762 & 0,840 & 0,712 & 0,636 & 0,647 & 0,673 & 0,675 & 0,708 & 0,686 & 0,693 & 0,763 & 0,760 & 0,857 & 1,156 & 1,026 \\
\hline Fibabanka A.Ș. & 0,578 & 0,782 & 0,891 & 0,685 & 0,483 & 0,510 & 0,596 & 0,678 & 0,629 & 0,732 & 0,788 & 0,875 & 0,980 & 0,799 & 1,946 \\
\hline Şekerbank T.A.Ş. & 0,930 & 0,910 & 0,890 & 0,793 & 0,852 & 0,668 & 0,697 & 1,050 & 0,711 & 0,732 & 0,849 & 0,833 & 0,828 & 0,429 & 0,641 \\
\hline Türk Ekonomi Bankası A.Ş. & 0,832 & 0,856 & 0,643 & 0,546 & 0,497 & 0,557 & 0,586 & 0,606 & 0,615 & 0,689 & 0,758 & 0,802 & 0,760 & 0,494 & 0,666 \\
\hline Türkiye İs Bankası A.Ş. & 0,986 & 0,902 & 0,850 & 0,740 & 0,957 & 0,901 & 0,891 & 0,873 & 0,693 & 0,698 & 0,780 & 0,827 & 0,828 & 1,825 & 1,651 \\
\hline Yapı ve Kredi Bankası A.Ş. & 0,769 & 0,895 & 0,888 & 0,702 & 0,665 & 0,912 & 0,899 & 0,745 & 0,678 & 0,717 & 0,789 & 0,814 & 0,845 & 0,744 & 0,876 \\
\hline \multicolumn{16}{|l|}{ Yabancı Sermayeli Bankalar } \\
\hline Alternatifbank A.Ş. & 1,146 & 1,284 & 0,891 & 0,797 & 1,125 & 1,473 & 0,678 & 1,156 & 0,905 & 0,975 & 1,504 & 1,136 & 0,951 & 1,848 & 1,207 \\
\hline Arap Türk B & 1,010 & 0,975 & 0,855 & 2,965 & 1,178 & 1,563 & 1,306 & 1,300 & 0,994 & 0,992 & 1,204 & 1,442 & 1,008 & 0,849 & 0,902 \\
\hline Bank Mellat & 0,871 & 0,919 & 0,914 & 0,752 & 0,787 & 1,137 & 4,115 & 1,698 & 2,616 & 4,192 & 4,837 & 16,209 & 3,230 & 3,256 & 3,783 \\
\hline Burgan Bank A.Ș. & 0,663 & 0,773 & 0,795 & 0,920 & 0,698 & 0,595 & 0,530 & 0,581 & 0,546 & 0,654 & 0,785 & 0,967 & 1,025 & 1,097 & 0,698 \\
\hline Citibank A.S. & 3,759 & 1,227 & 2,031 & 0,780 & 3,400 & $\underline{1,835}$ & 1,048 & 4,030 & $\underline{5,878}$ & 6,942 & 4,911 & 5,163 & 5,861 & 9,087 & 9,987 \\
\hline Denizbank A.Ș. & 0,913 & 0,952 & 0,692 & 0,683 & 0,919 & 0,879 & 1,342 & $\overline{0,762}$ & 0,770 & 0,718 & 0,780 & 0,774 & 0,793 & 0,490 & 0,745 \\
\hline Habib Bank Limited & 1,779 & 0,974 & 3,312 & 1,465 & 1,509 & 1,301 & 1,619 & 2,169 & 0,972 & 0,975 & 1,044 & 0,944 & 0,820 & 0,616 & 0,762 \\
\hline HSBC Bank A.Ş. & 0,949 & 0,988 & 0,774 & 0,643 & 0,622 & 0,686 & 0,820 & 0,665 & 0,637 & 0,583 & 0,616 & 0,696 & 0,990 & 0,718 & 0,650 \\
\hline ICBC Turkey Bank A.S. & 0,770 & 0,859 & 0,705 & 0,610 & 0,604 & 0,584 & 0,620 & 0,729 & 1,881 & 0,721 & 0,786 & 0,666 & 0,781 & 0,616 & 0,686 \\
\hline ING Bank A.S. & 0,856 & 0,835 & 0,652 & 0,606 & 0,671 & 0,665 & 0,708 & 0,953 & 0,697 & 0,723 & 0,826 & 0,807 & 0,818 & 0,754 & 0,734 \\
\hline QNB Finansbank A.Ș. & 1,041 & 1,096 & 0,790 & 0,683 & 0,697 & 0,716 & 0,671 & 0,819 & 0,694 & 0,695 & 0,768 & 0,767 & 0,727 & 0,595 & 0,751 \\
\hline Turkland Bank A.Ş. & 0,768 & 0,675 & 0,584 & 0,511 & 0,510 & 0,709 & 0,614 & 0,625 & 0,651 & 0,723 & 0,720 & 0,787 & 0,778 & 0,588 & 0,429 \\
\hline Türkiye Garanti Bankası A.Ş. & 0,920 & 0,958 & 1,208 & 0,840 & 0,841 & 0,837 & 0,908 & 0,769 & 0,790 & 0,789 & 0,860 & 0,938 & 0,948 & 0,785 & 0,901 \\
\hline
\end{tabular}


Veri zarflama yönteminden yola çıkarak hazırlanan süper etkinlik analizinin incelenmesi sonucunda 2005, 2009, 2010, 2012, 2013, 2014, 2015, 2017, 2018 ve 2019 yıllarında Citibank en etkin banka konumunda bulunmaktadır. 2011 ve 2016 yıllarında Bank Mellat, 2006'da Vakıfbank, 2007'de Habib Bank Limited ve 2008 yılında Arap Türk Bankası en etkin bankalar konumunda bulunmuşlardır.

Kamu sermayeli bankalar seçtiğimiz 2005-2019 dönemi içinde 2006'da Vakıfbank'ın haricinde en etkin konumda bulunmamıştır. Kamusal bankaları genel olarak incelediğimizde ise etkinlik olarak Halk Bankası yıllar itibari ile Ziraat Bankası ve Vakıfbank'a göre karşılaştırmalı olarak daha fazla defa etkin konumda bulunmuşlardır.

Özel sermayeli bankalardan hiçbiri analiz yapılan yıllar içinde en etkin konumda bulunmamıştır. Genel olarak özel sermayeli bankalar diğer banka türlerine göre etkinsiz olarak öne çıkmaktadır.

Yabancı sermayeli bankalar süper etkinlik sonuçlarına göre genel olarak en etkin bankalar oldukları belirlenmiştir. Bu bankalar içinde Citibank 15 yılın 10'unda en etkin konumda bulunmuştur. Bank Mellat 15 yılda 2, Arap Türk Bankası 1 ve Habib Bank Limited 1 defa olmak üzere, yabancı bankalar 15 yılın 14 'ünde en etkin konumda bulunmuşlardır. Bu bankaların aktif büyüklük payları sektör içinde oldukça küçük düzeydedir (Citibank binde 2,6, Arap Türk Bankası binde 1,55, Bank Mellat onbinde 2,6 ve Habib Bank Limited yüz binde 5). En etkin düzeyde bulunmaları bankaların en iyi veya en büyük banka olduklarını değil belirlediğimiz girdileri daha etkin kullanıp diğer bankalara kıyasla daha verimli çıktılar elde ettiklerini göstermektedir.

\subsection{Malmquist Toplam Faktör Verimlilik Analizi Sonuçları}

Verimlilik analizi ele alınan dönemde yıl bazında bankaların ne kadar verimli çalıştıklarını göstermektedir. Verimlilikteki değişimi yıllar itibariyle incelemek için kullanılan Malmquist TFV analizinin sonuçları Tablo 4'te verilmiştir. 
Tablo 4: 2005-2019 Yilları Arasinda Bankaların Malmquist Toplam Faktör Verimliliği Endeksi Değiş̧imleri

\begin{tabular}{|c|c|c|c|c|c|}
\hline & TED & TD & STED & ÖED & TFVD \\
\hline Bankalar & 0,989 & 1,696 & 0,980 & 0,965 & 1,680 \\
\hline Kamusal Sermayeli Mevduat Bankaları & 0,933 & 1,579 & $\mathbf{0 , 9 3 3}$ & 1,000 & 1,474 \\
\hline T.C. Ziraat Bankası & 0,932 & 1,495 & 0,932 & 1,000 & 1,393 \\
\hline Türkiye Halk Bankası & 0,925 & 1,575 & 0,937 & 0,986 & 1,456 \\
\hline Türkiye Vakıflar Bankası & 0,943 & 1,667 & 0,931 & 1,013 & 1,573 \\
\hline Özel Sermayeli Mevduat Bankaları & 0,982 & 1,654 & 0,976 & 0,863 & 1,628 \\
\hline Akbank T. & 0,938 & 1,581 & 0,975 & 0,962 & 1,484 \\
\hline Anadolubank & 1,005 & 1,748 & 1,000 & 1,005 & 1,757 \\
\hline Fibabanka & 1,026 & 1,762 & 1,000 & 1,026 & 1,808 \\
\hline Şekerbank T. & 1,026 & 1,686 & 1,000 & 1,026 & 1,729 \\
\hline Türk Ekonomi Bankası & 1,023 & 1,709 & 1,000 & 1,023 & 1,748 \\
\hline Türkiye İş Bankası & 0,925 & 1,557 & 0,928 & 0,996 & 1,439 \\
\hline Yap1 ve Kredi Bankası & 0,932 & 1,536 & 0,929 & 0,004 & 1,433 \\
\hline Yabancı Sermayeli Bankalar & 1,005 & 1,746 & 0,993 & 1,012 & 1,756 \\
\hline Alternatifbank & 1,026 & 1,728 & 1,000 & 1,026 & 1,773 \\
\hline Arap Türk Bankası A.Ş. & 1,007 & 1,817 & 1,000 & 1,007 & 1,829 \\
\hline Bank Mellat & 1,023 & 1,764 & 1,000 & 1,023 & 1,804 \\
\hline Burgan Bank & 1,000 & 1,679 & 1,000 & 1,000 & 1,679 \\
\hline Citibank A,Ş, & 1,016 & 1,679 & 1,001 & 1,015 & 1,705 \\
\hline Denizbank & 1,026 & 1,671 & 1,000 & 1,026 & 1,715 \\
\hline Habib Bank Limited & 1,025 & 1,902 & 1,000 & 1,025 & 1,950 \\
\hline HSBC Bank & 1,027 & 1,771 & 1,000 & 1,027 & 1,819 \\
\hline ICBC Turkey Bank & 1,001 & 1,718 & 1,000 & 1,001 & 1,720 \\
\hline ING Bank & 1,029 & 1,768 & 1,000 & 1,029 & 1,820 \\
\hline QNB Finansbank & 0,937 & 1,634 & 0,961 & 0,974 & 1,530 \\
\hline Turkland Bank A,Ş, & 1,019 & 1,808 & 1,000 & 1,019 & 1,842 \\
\hline Türkiye Garanti Bankası & 0,930 & 1,761 & 0,944 & 0,985 & 1,637 \\
\hline \multicolumn{6}{|c|}{$\begin{array}{l}\text { TED: Teknik Etkinlikteki Değişme, } \\
\text { TD: Teknolojik Değişme, } \\
\text { SED: Saf Etkinlikteki Değişme, } \\
\text { ÖED: Ölçek Etkinliğindeki Değişme, } \\
\text { TFVD: Toplam Faktör Verimliliğindeki Değişme }\end{array}$} \\
\hline
\end{tabular}

Tablo 4'te görüldüğü gibi teknik etkinlikteki değişme endeksi incelendiğinde \% 61 (23 bankanın 14'ü ) teknik etkinliğinde ilerleme olduğu gözlemlenirken \%35 ( 23 bankanın 8'u)'unda ise teknik etkinlikte gerileme olduğu, tespit edilmiştir. Teknik etkinlikle durağan $(\mathrm{ED}=1)$ olan 1 banka 
bulunmaktadır. Analiz sonucuna göre teknik etkinlikte ilerleme sağlayan bankalarda ING Bank, HSBC, Denizbank, Alternatif Bank, Şekerbank ve Fibabanka ilk sıraları paylaşmaktadır. İş Bankası, Halkbank ve Garanti Bankası ise en yüksek gerileme oranına sahip ilk üç bankadır. Bankalar bazında yabancı sermayeli bankalar, kamu sermayeli ve özel sermayeli bankalara göre daha etkin çıkmıştır.

Teknolojik etkinlikte gerileme olan banka tespit edilmemiştir. Teknolojik etkinlikte en yüksek ilerlemeye sahip banka Habib Bank Limited iken bunu Arap Türk Bankası ve Turkland takip etmektedir. Teknolojik etkinlikte kamu sermayeli bankalar yabancı sermayeli ve özel sermayeli bankalara göre geri planda kalmaktadır.

Toplam faktör verimliliği değişim endeksi teknik etkinlikteki değişim ile teknolojik değişimin çarpılmasının sonucunda elde edilmektedir. TFVD'ye göre analize dahil olan bankalardan gerileme gözlemlenmemektedir. TFVD'de en yüksek ilerlemeye sahip bankalar Şekerbank, Habib Bank Limited ve Turkland Bank'tır. Banka grubu bazında en yüksek ilerleme Yabancı Sermayeli Mevduat Bankalarına aittir. TFVD'deki değişme teknik etkinlikteki değişme ve teknolojik değişmenin çarpımından elde edilmektedir. Teknolojik değişme değerleri daha yüksek düzeyde olduğu için TFVD'yi de en çok teknolojik değişme etkilemektedir.

TFV endeksi değişimi yabancı bankalarda \%75,6, özel sermayeli bankalarda \%62,8 ve kamu bankalarında \% 47,4 oranında artış gözlenmiştir.

\section{Sonuç}

Finans sisteminin içinde en büyük paya sahip olan bankacıllk sektörünün etkinliği büyük öneme sahiptir. Bankaların etkin çalışmaları bankaların ve sektörün gelişim ve büyümesi için çok önemlidir. Finansal sistemin temel yapı taşı olan bankacılık sisteminin sağlam, güçlü ve istikrarlı olması gerekir. 2001 yılında Türkiye ekonomisinde yaşanan bankacılık krizi ekonominin \%5,9 küçülmesine neden olmuştur. Türkiye ekonomisinde bankaların en önemli finansal aracıların başında geldiği dikkate alındığında, bankacılık sektöründe yaşanan olumsuz ya da olumlu gelişmelerin finans sistemine ve ülke ekonomisine etkisi o denli büyük olmuştur. Finansmana erişimin artması, en son teknolojileri kullanan bankacılık sektörü içinde yaşanan rekabet olgusu, bankaların verimliliğini artırarak sektörün sürekli gelişim ve değişim göstermesini sağlamaktadır.

Toplam 53 bankanın bulunduğu bankacılık sektörünün 34'ü mevduat, 13'ü kalkınma ve yatırım ve 6'sı da katılım bankasıdır. Analize kalkınma ve yatırım ile katılım bankaları dahil edilmemiştir. Kalkınma ve yatırım bankalarının dahil edilmeme sebebi işleyiş ve yapısının diğer banka türlerinden tamamen farklı olmasıdır. Katılım bankalarının dahil edilmemesinin sebebi ise kullanılan girdi ve çıktıların (faiz ve faiz dışı gelir-gider) katılım bankaları açısından bir karşılığının olmamasıdır. 34 mevduat bankasının toplam aktif büyüklüğü yüzde 
87 iken toplam 20 olan kalkınma ve yatırım bankaları ile katılım bankalarının sektördeki toplam payı yüzde 13 civarındadır. 34 tane mevduat bankasının kesintisiz verilerine ulaşılan 23 tanesi analize dahil edilmiştir. Analize dahil edilen 23 bankanın aktif büyüklük toplamı ise bankacılık sektörünün yaklaşık \%86'sını oluşturmaktadır. Girdi olarak şube sayısı, personel sayısı, faiz giderleri, faiz dışı giderler ve çıktı olarak faiz gelirleri ile faiz dışı gelirler kullanılmıştır.

Analiz sonuçlarına göre şube sayısı, personel sayısı, faiz ve faiz dışı giderlerin faiz ve faiz dışı gelirler açısından 2005-2019 yılları aralığında Kamusal sermayeli bankalar içinde Halk bankasının belirlenen girdi ve çıktılar açısından en etkin konumda olduğu görülmüştür. Daha açık bir ifadeyle Halk bankasının faiz ve faiz dışı gelirlerin oluşturulmasında en uygun şube sayısı, personel sayısı, faiz giderleri, faiz dışı gider bileşimine sahip olduğu anlaşılmaktadır. Yabancı sermayeli bankalardan Citibank ve Arap Türk Bankasının belirlenen girdi ve çıktılara göre daha etkin çalıştığı belirlenmiştir. 2008 krizinin etkisiyle sektör olarak etkinlik oranlarında düşüş meydana gelmiştir. 2018 yılına göre 2019 y1lı sonuçlarına bakıldığında ise analize dahil edilen bankaların yaklaşık \%61'inin (23 bankadan 14'ü) etkinliklerinde artış meydana gelmiştir.

Etkinlik sıralamasını gösteren süper etkinlik değerlendirmesinde Citibank'ın ön plan çıktığı görülmektedir. Süper etkinlik sonuçlarına genel olarak bakıldığında yabancı sermayeli bankalar diğer banka gruplarına göre daha etkin durumdadır. Yabancı sermayeli bankalardan etkinlikleri en yüksek düzeyde olan bankalar genellikle aktif büyüklüğü düşük bankalar olmakla birlikte belirlenen girdileri daha etkin kullanıp diğer bankalara kıyasla daha verimli çıktılar elde eden bankalardır.

Teknolojik etkinlikte gerileme olan banka tespit edilmemiştir. Teknolojik etkinlikte kamu sermayeli bankalar yabancı sermayeli ve özel sermayeli bankalara göre geri planda kalmaktadır. Kamu bankalarının diğer bankalar ile rekabetini güçlendirmeleri için teknolojik altyapılarını güçlendirmeleri gerekmektedir. TFVD'e göre analize dahil olan bankalardan gerileme gözlemlenmemektedir. TFVD'de en yüksek ilerlemeye sahip bankalar Habib Bank Limited, Turkland Bank, Arap Turk Bank ve ING Bank’tır. Banka grubu bazında en yüksek ilerleme yabancı sermayeli mevduat bankalarına aittir. TFVD'deki değişme daha çok teknolojik değişimden etkilenmektedir.

Bu doğrultuda yabancı sermayeli bankaların teknolojik altyapısının daha güçlü olduğu bulgusundan hareketle Türk kamu ve özel bankaların bu gelişmelerin gerisinde kalmaması için teknik altyapı ve donanımı sağlayarak teknolojik gelişmeleri daha yakından takip etmesi önerilmektedir. 
Ticari Bankaların Etkinliklerinin VZA ve Malmquist TFV Endeksi ile İncelenmesi

\section{Kaynaklar}

Abbas, M., Hammad, R. S., Elshahat, M. F., ve Azid, T. (2015). "Efficiency, Productivity and İslamic Banks: An Application of DEA and Malmquist İndex". Humanomics, 31(1). 118-131. Retrieved from, https://search.proquest.com/docview/16505 61731? accountid=8403

Ada, A. A. ve Dalkılıç, N. (2014), "Efficiency Analysis in Islamic Banks: A Study for Malaysia and Turkey", BDDK Bankacillk ve Finansal Piyasalar, 8(1), 9-33

Akyüz, Y., Y1ldı, F. ve Kaya, Z., (2013) "Veri Zarflama Analizi (VZA) ve Malmquist Endeksi İle Toplam Faktör Verimlilik Ölçümü: BIST'te İşlem Gören Mevduat Bankaları Üzerine Bir Uygulama", Atatürk Üniversitesi İktisadi ve İdari Bilimler Dergisi, 27(4), 110-130.

Andersen, P. ve N.C., Petersen, (1993), “A Procedure for Ranking Efficient Units in Data Envelopment Analysis", Management Science 39(10): 1261-1264.

Ateş, A. ve Esmer, S. (2013). "VZA Malmquist Toplam Faktör Verimlilik Endeksi: 2009 Küresel Finans Krizinin Türk Konteyner Terminallerine Etkisi", II. Ulusal Lojistik ve Tedarik Zinciri Kongresi Bildiriler Kitabı, $75-84$

Bakırcı, F., (2006). Üretimde Etkinlik ve Verimlilik Ölçümü Veri Zarflama Analizi Teori ve Uygulama . Ankara: Atlas Yayınları

Bankac1lık Düzenleme ve Denetleme Kurumu, BDDK, https://www.bddk.org.tr/

Banker RD, Charnes A, Cooper WW (1984). Some Models for Estimating Technical and Scale Inefficiency in Data

Banker, R.D., Cooper, W.W., Seiford, L.M., Thrall, R.M., Zhu, J. (2004), "Returns to Scale in Different DEA Models", European Journal of Operational Research, Vol. 154, pp.345-362.

Behdioğlu, S. ve Özcan, G. (2009) "Veri Zarflama Analizi ve Bankacilık Sektöründe Bir Uygulama", Süleyman Demirel Üniversitesi İktisadi ve İdari Bilimler Fakültesi Dergisi, 14 (3), 301-326.

Bektaş, H., (2013), Türk Bankacılık Sektöründe Etkinlik Analizi, Sosyoekonomi, 19 (19) : 277-294

Bolaman Avcı Ö. ve Öztaş Gülin Z. (2016), "Türk Bankacılık Sektöründe Etkinlik 19982014 Döneminde Veri Zarflama Analizi Uygulaması", Bankac1lar Dergisi, 97, 37-72.

Boussofiane, A., Dyson, R. ve Rhodes, E. (1991). “Applied Data Envelopment Analysis", European Journal of Operational Research, Vol. 52, No. 1, pp. 1-15.

Buğan, M., F., (2015). Katılım Bankaları İle Konvansiyonel Bankaların Etkinliklerinin VZA ve Malmquist TFV Endeksi İle Karşılaştırılması, (Yayınlanmış Yüksek Lisans Tezi), Gaziantep: Gaziantep Üniversitesi 
Budak, H. (2011). "Veri zarflama analizi ve Türk bankacılık sektöründe uygulaması", Marmara Üniversitesi Fen Bilimleri Dergisi, 23(3), 95110.

Büyükakin, F., ve Kapkara, S. (2016), "Katılım Bankalarının Veri Zarflama Yöntemi İle Verimlilik Ve Etkinlik Analizi Üzerine Bir Değerlendirme (2010-2015 Dönemi)" International Congress of Management Economy and Policy (pp.388-410). İstanbul, Turkey.

Caves, D., Christensen, L., ve Diewert, W. (1982). Multilateral Comparisons of Output, Input, and Productivity Using Superlative Index Numbers. The Economic Journal, 92(365), 73-86. DOİ:10.2307/2232257

Charles V. ve Kumar M. (2012). "Data Envelopment Analysis and Its Applications to Management", Cambridge Scholars Publisher, ProQuest Ebook Central, Retrieved from https://search.proquest.com/ legacydocview/EBC/1133039? accountid=8403

Charnes, A., Cooper, W.W. , Rhodes, E. ,(1978), "Measuring the Efficiency of Decision Making Units", European Journal of Operation Research, 429-444.

Cooper, W. W., Seiford, L. M. ve Tone, K. (2006). Data Envelopment Analysis: a Comprehensive Text With Models, Applications, References and DEA-Solver Software (2. bs): Springer Science \& Business Media.

Çelik Ş., Öncü E. ve Yenice S. (2018), “Türkiye'deki Bankaların Karşılaştırmalı Etkinlik Analizi”, İş̧etme Araştırmaları Dergisi, 10, 156171

Çolak, Ö. ve Öçal, T. (1999). Finansal Sistem ve Bankalar, Ankara: Nobel Yayınları.

Deliktaş, E. (2002). "Türkiye Özel Sektör İmalât Sanayiinde Etkinlik ve Toplam Faktör Verimliliği Analizi" Odtü Gelişme Dergisi, 29(3-4):247-284.

Eken, M.H. ve Kale, S. ,(2011), "Measuring Bank Branch Performance Using Data Envelopment Analysis: The Case of Turkish Bank Branches", African Journal of Business Management, 5(3): 889-901.

Fare R., Grosskopf, S., Norris M., Zong Z.Y (1994). "Productivity Growth Technical Progress and Efficiency Change in Industry", American Economic Review Combine with Journal of Economic Literature and Journal of Economic Perspect, N.84, 66-80.

Farrell, M.J. (1957), The Measurement of Productive Efficiency. Journal of the Royal Statistical Society: Series A (General), 120: 253-281. doi: $10.2307 / 2343100$

Hajıhassanıasl, S. ve Nasırı, N. (2019). “İran’da Seçilmiş Bankaların Etkinlik Analizi: 2013-2016 Doğu Azerbaycan Örneği’”, İktisadi İdari ve Siyasal Araştırmalar Dergisi, 4(8), 72-90, DOI: 10.25204/iktisad.484517

Jreisat, A. ve Paul, S., (2011), "Technical Efficiency of Jordanian Banking Sector Based on DEA Approach", Terengganu International Finance and Economics Journal, 1. 11-24. 
Keskin Benli, Y. (2012), "Veri Zarflama Analizi (VZA) ve Malmquist Toplam Faktör Verimliliği (TFV): Konaklama İşletmelerinde Bir Uygulama" , Ege Akademik Bakış, 12(3), 369-382.

Khan, M S J., Samsudin, S. ve Islam, R. (2017), "Efficiency of banks in Southeast Asia: Indonesia, Malaysia, Philippines and Thailand", International Journal of Social Economics, Vol. 44 No. 12, pp. 2302-2312. https://doi.org/10.1108/IJSE-01-2016-0020

Öner, M. ve Demirel Arıcı, N.. (2018). "Türk Bankacılık Sektörünün Etkinlik ve Verimlilik Analizi: 2012-2017 VZA ve Malmquist TFV Endeksi Uygulaması", Bankacılar Dergisi, Say1 106, 18-36

Özdemir, D., Topçuoğlu, Ö. ve Kişioğlu Ö. F. (2019). "Vergi Harcamalarının Vergi Gelirleri Açısından Etkinliği: 2006-2018 Döneminin Değerlendirilmesi”, Maliye Dergisi, 176: 380-405

Özer, H., ve Topçuoğlu, Ö.. (2017). "Türk Çimento Sektöründe MülkiyetEtkinlik İlişkisi: Vza ve Tobit Model Uygulaması”. Verimlilik Dergisi, (4). 141-168. Retrieved http://dergipark.org.tr/verimlilik/issue/31514/345315

Ray, Subhas C., (2004), "Data Envelopment Analysis: Theory and Techniques for Economics and Operations Research", New York: Cambridge University Press.

Sherman, H. D. ve Gold, F., (1985), "Bank branch operating efficiency: Evaluation with Data Envelopment Analysis", Journal of Banking \& Finance, 9(2), 297-315

Sufian, F. ve Noor, M. (2009), "The determinants of Islamic banks' efficiency changes: Empirical evidence from the MENA and Asian banking sectors", International Journal of Islamic and Middle Eastern Finance and Management, Vol. 2 No. 2, pp. 120-138. https://doi.org/10.1108/17538390910965149

Tone, K., (2004). "Malmquist Productivity Index" Handbook on Data Envelopment Analysis, Springer US.

Ulucan, A. ve Karacabey, A. A., (2002), "IMKB Hisse Senedi Piyasasının Teknik Etkinliğinin AB Aday ve Üye Ülkelerle Karşılaştırmalı Analizi”, Ankara Avrupa Çalışmaları Dergisi, 2 (3), 101-111. 